\title{
Bridging crop diversity and market development in the Northeast grain renaissance
}

\author{
Henry R. Blair ${ }^{a} *$ \\ GrowNYC \\ Carolyn Dimitri ${ }^{\mathrm{b}}$ \\ New York University
}

Submitted October 27, 2017 / Accepted October 27, 2017 / Published online December 20, 2017

Citation: Blair, H. R., \& Dimitri, C. (2017). Bridging crop diversity and market development in the

Northeast grain renaissance. Journal of Agriculture, Food Systems, and Community Development, 7(4), 51-60.

http://dx.doi.org/10.5304/jafscd.2017.074.015

Copyright (C) 2017 by New Leaf Associates, Inc.

\begin{abstract}
The local food movement has grown significantly over the past several years, producing and marketing fresh fruits and vegetables, and meat and dairy. Recently there has been a push in the Northeastern U.S. to grow small grains, primarily high-protein wheat varieties for baking bread and for malting barley for brewing and distilling, for local and regional markets. University researchers, nonprofit organizations, and government institutions are supporting this advance in the regional food system by working with farmers to increase production of these crops and develop markets for their sale. This paper argues that these farming systems, starting with the early stages of
\end{abstract}

a * Corresponding author: Henry R. Blair, Greenmarket Regional Grains Project; 100 Gold Street, Suite 3300; New York, NY 10038 USA; +1-917-837-0678; henryrblair@gmail.com

b Department of Nutrition and Food Studies, New York University; 411 Lafayette Street, $5^{\text {th }}$ Floor; New York, NY 10003 USA; carolyn.dimitri@,nyu.edu field crop production work, should include diverse crop rotations that will provide farmers with multiple revenue streams, improve soil quality, and reduce the incidence and severity of pest outbreaks. Consumers in the existing and developing regional grain market will benefit from increased availability of fresh, flavorful, and healthy grains, beans, and oilseeds. The paper draws connections between the farming, research, and market-development communities that are working toward improved farm biodiversity.

\section{Keywords}

Collaboration; Development; Diversity; Field Crops; Grain; Markets; Regional; Resilience; Rotation

\section{Disclosure}

Henry Blair works for GrowNYC's Greenmarket Regional Grains Project, a nonprofit organization that operates in this field. The program may be eligible for grants or other funding for outcomes discussed in this paper. 


\section{Introduction}

Since the 1970s, the local and regional food movement has grown significantly, with evidence of the shift abundant on multiple fronts. Thus, it is not uncommon today for consumers to inquire about the origins of food and demand transparency. Food companies label products as "natural," "local," "family farm," and so forth to offer clarity to their customers. Municipalities are investing in urban agriculture programs, states are promoting food hubs and local labels, such as Colorado Proud, NY Grown and Certified, Made in Montana, and PA Preferred, and the federal government is investing as well in organic agriculture and crop diversification (Low et al., 2015). At the farm level, farms marketing directly to consumers increased 17 percent from 2002 to 2012, and farmers markets increased 180 percent between 2006 and 2014 (Low et al., 2015). Such changes have resulted in robust farm production for local markets, as farmers produced US $\$ 8.6$ billion worth of edible products sold in local markets in 2015 (U.S. Department of Agriculture, National Agricultural Statistics Service [USDA NASS], 2016).

Until recently, much of the local food attention has focused on fresh fruit, vegetable, meat, and dairy production, leaving field crops largely out of the discussion. For good reasons, local and regional food advocates have turned their attention to grain production to increase the diversity of locally and regionally produced foods. Grains make up a significant portion of diets, suggesting that a ready market exists. Furthermore, ancient and heritage grains, the types most compatible with local and regional food systems, offer rich genetic diversity, which is compelling to farmers seeking stress tolerance and adaptability.

Nationally, four of the ten top states producing for local markets are in the Northeast ${ }^{1}$ : Massachusetts (MA), New York (NY), Pennsylvania (PA), and Vermont (VT) (USDA NASS, 2016). Furthering this strong regional interest in local production, Northeast farmers have been working directly with millers, maltsters, bakers, and brewers for grain variety selection and production feedback. Once

${ }^{1}$ The nine states that make up the Northeast are Maine, Vermont, New Hampshire, Massachusetts, Connecticut, appropriate varieties are identified, selection and crossing for modern wheats follow. The ancient and heritage grains suitable for the regional climate are varieties once readily found in the Northeast when farms were more diversified, before the nationalization of agriculture. Ancient and heritage wheats have greater genetic diversity and offer traits with more resistance to pest and disease pressure, and sometimes are more resilient to drought and excess moisture. Selecting and crossing ancient and heritage varieties produces hardier and more resilient crops for the Northeast (Rogosa, 2012). Rebuilding the regional system for grains from the early stages of cultivation presents an opportunity to implement diverse and ecologically sound production models.

Targeting regional markets for the reestablishment of grain production involves selecting varieties for flavor, preserving the identity and integrity of products and producers, and relieving the negative social and environmental damage created by intensive monocrop agriculture (Cornell University, 2017; Rogosa, 2016). Markets available to regionally grown small grains and rotation crops include home cooks and bakers, brewers and distillers, restaurants and bakeries, institutions such as schools and hospitals, livestock farms, biofuel companies, and food processors. Ancient and heritage grains especially pique the interests of chefs and bakers, who seek out their complex flavor profiles for higher quality end-products (Cornell, 2017). These markets have begun to open for grain growers in the Northeast and may be further expanded as production increases.

Actively fostering environmental qualities, such as biodiversity and soil quality, is an important component of thoughtfully developing a regional market for grains. Crop rotation is a crucial aspect, as farms are healthier systems when grains are grown in sequence with other crops, such as dry beans, oilseeds, and forages. Crop rotation, biodiversity, and soil conservation have been identified as key elements of sustainable farm management (Kirschenmann, 2010). Diverse crop rotations have many benefits for the farm ecosystem.

Rhode Island, New York, Pennsylvania, and New Jersey. 
These systems cycle and make available macro- and micronutrients in the soil, add organic matter to the soil to improve aeration and granulation, increase both water-holding capacity and drainage, disrupt pest cycles, provide additional revenue streams in the event of crop failure, promote beneficial microbial, insect and wildlife habitat, and slow soil erosion (Kirschenmann, 2010; Kroeck, 2011; Lazor, 2013; Lengnick, 2015; Rogosa, 2016).

To effectively promote crop biodiversity on the farm, it is important to build markets for various rotation crops. It is less compelling for farmers to dedicate time, energy, and land to harvests that are unmarketable. Input costs are high for grain farms: cultivation, harvest, and cleaning and storage equipment are expensive to purchase and maintain. The supply of clean, high-quality seed for field crops is low in the Northeast, and prices are often high, especially for heritage grains and heirloom beans. Seed saved on farms or from unknown sources may be contaminated with disease and weed seed (Lazor, 2013). It is difficult to make the case to farmers to grow crops which require additional resources, such as time and handling space, and which then may not be sold (Rogosa, 2012).

Based on the relevant literature and several years of experience working and studying in the field, we make a case for active market development for rotation crops so that farmland in field crop production is improved, farmers can adopt systems for profitable crop diversity, new businesses that use various field crops can emerge and grow, and consumers are able to buy a greater variety of local farm products.

\section{History of Grain Production in the Northeast} In the mid- to late- $19^{\text {th }}$ century, technological advances in farm and food processing, widespread construction of canals and railroads, and new breeding techniques to select for high-yielding spring-sown wheat varieties drew grain production from the Northeast to the Midwestern states (Cronon, 1991; Lazor, 2013; Rogosa, 2016). Landscapes in the west were vast and transportation became cheap. The development of the grain reaper and combine in the 1830s, the grain elevator in the 1840s, and the roller mill in the 1870s allowed for significant economies of scale in grain production, storage, processing, and transportation to take hold over the course of the century (Cronon, 1991; Jacob, 2007). Farmers in the Midwest produced ever larger quantities of grain, seed companies and food processors expanded, and field crop production became fully industrialized and specialized (Cronon, 1991; Jacob, 2007; Kroeck, 2011). Food processing and manufacturing increased across the country into the $19^{\text {th }}$ century. These efficiencies made it possible for fewer farmers to produce greater quantities of food.

While the Midwest expanded these technologies to increase production, the Northeast struggled to compete. Markets for Northeastern wheat expanded during the Civil War, and farmers planted it continuously for several years. Lack of crop rotation, however, mined soils of nutrients over time and increased pest pressure. Outbreaks of Hessian fly and black stem rust, and degraded soils, combined with the inability to compete with Midwestern farmers, convinced farmers in New York to discontinue grain production and either shift to and specialize in more perishable goods, such as dairy and fresh vegetables, or forgo farming altogether (Kroeck, 2011; Lengnick, 2015).

The departure of Northeast grain farms rippled through the region. Throughout the $20^{\text {th }}$ century, mills, malt houses, breweries, and distilleries in the Northeast shut down (Platel \& Russell, 2015). During this time, advances in farming, food processing, and transportation technologies continued, allowing for increased yield and production efficiency with less human labor in the supply chain. Knowledge of grain husbandry and value-adding in the region became more fragmented and attenuated over the course of the $20^{\text {th }}$ century. Existing grain cultivation and handling equipment fell into disrepair and most new machinery was designed for the massive-scale farms in the Great Plains. Though breweries and distilleries remained in New York through the $19^{\text {th }}$ century and into the $20^{\text {th }}$, they quickly closed during Prohibition. Grain elevators across the region remained vacant, mills were abandoned and destroyed, and midscale processing became non-existent (Platel \& Russell, 2015). Market forces and technological development, combined with inadequate cropping systems 
and poor land stewardship, led to the collapse of the Northeast grains economy.

This reflects broader changes in the agricultural sector. Between 1910 and 1970, U.S agricultural output nearly doubled, while farm acreage decreased; farm labor decreased 54 percent from 1950 to 1972 , while labor productivity quadrupled and total farm output increased 55 percent (Heady, 1976). As crops became standardized on large Midwestern farms, grains lost their specificity and traceability. At the same time, due to standardizing commodities for baking and distilling, baked goods and spirits lost their local character and, consequently, consumers became further removed from food production (Halloran, 2015).

Despite this collapse of regional infrastructure, some farmers continued to produce crops, mainly rye, oats, corn, and buckwheat, for the emerging dairy industry (Platel \& Russell, 2015). The backto-the-land movement of the 1970s exhumed some of the old knowledge and slowly brought back grain farming and milling on a small scale. Many of these farmers and processors continue to be highly valuable resources for the development of robust and resilient regional grain and field crop production. They produce various crops for growing markets and are valuable mentors to new growers.

\section{Current and Developing Regional Grain Markets}

The Northeastern grains movement has grown significantly since 2009. The impact of the revival is visible in every sector of the supply chain, which is developing as more farms grow grains for regional markets and as mills and malt houses are built to process grain. The intermediaries-breweries, distilleries, bakeries, and restaurants - are seeking sources of regional grain products for the growing consumer demand. Support structures, such as extension and testing services, are developing expertise and best practices for grain cultivation and quality analysis. (Kucek et al., 2017). A great deal of literature is being produced about local and regional grain systems for farm stewardship and concerns such as environmental health, human health, local food systems, and flavor (Bland, 2013; Halloran, 2015; Koenig, 2010; Mars, 2015; Razon, 2017; Rogosa, 2016; Sen, 2015). Because grain needs to be carefully tested, cleaned, and processed before coming to market, institutional support and policy levers are activating across the region.

Northeast communities have engaged with grain growers and processors to strengthen their economies. Since 2010 this kind of work has been occurring in central and northern Maine, led by the Maine Grain Alliance (MGA) and the Somerset Gristmill. MGA formed with a mission to increase grain production in Maine for the economic benefit of farmers, support of the local economy, and provision of high quality, local food for consumers (MGA, n.d.). The Somerset Gristmill acts as a liaison between growers and consumers, judging grain baking quality, testing for disease, and developing markets. The availability of local grain has led to the growth of malt houses, breweries and bakeries, and related tourism in the area.

Many other organizations in the Northeast are having a similar impact. In Vermont, the Northern Grain Growers Association (NGGA) formed in 2004 to support existing regional grain growers and encourage expansion. The group engages various stakeholders across the region to share research and best practices for grain production and processing (NGGA, n.d.). The Organic Growers' Research and Information-Sharing Network (OGRIN) began in New York to conduct on-farm research of organic production practices. It has acted as a liaison between the research and farming communities, providing valuable insight into the development of sustainable, regional organic farming (OGRIN, 2017). Heritage Grain Conservancy (HGC), a farmer-owned research program in Massachusetts, researches and shares best production practices for ancient and heritage wheats that exhibit strong potential for Northeast production (HGC, n.d.). The HGC also offers seed and planting guidelines for regional farmers. The Northeast Organic Farming Association (NOFA) chapters in Massachusetts and New York have also hosted workshops, field days, and lectures to showcase growing practices and offer market assistance to Northeast organic farmers interested in grain production (NOFA/Mass, 2014).

Technical assistance is becoming more readily available to growers through extension services offered by the land-grant university system. 
Pennsylvania State University (PSU) offers a webinar outlining organic grain quality indicators and information about the production of highquality organic heritage wheat (PSU, 2013). Cornell offers advice for growing high-quality specialty small grains and has a robust small grains breeding program (O'Dea, 2013). The University of Vermont (UVM) supports grain and dry bean growers in the state, with a lab for quality analysis (UVM Extension, 2017).

It is vital for sustainable growth of a regional grain system to include development of substantial markets for the critical rotation crops. Despite all that the research and farming communities know about the health of complex rotation systems and ecologically balanced farming methods, the need for economic viability is often a deciding factor for increasing crop diversity. It is important to recall the practices and events of the $19^{\text {th }}$ century, when resources were treated as unlimited and markets for a select few specific crops were insatiable: crop loss and systems collapse ensued.

The Greenmarket Regional Grains project has been developing the market for food grains in New York City since 2004. First, the project began conducting supply chain and market outreach and education. In 2009, Greenmarket adopted a rule requiring the use of local flour in all baked goods sold at over 50 Greenmarkets across the city. In 2014, the program grew to include the Grainstand, a retail booth for education, outreach, and sales of grains and flours at target markets (GrowNYC, 2016). Local flour can now be found in many shops, grocery stores, and bakeries across the city, and the mill businesses have grown tremendously. This is just one market locale of many across the Northeast, from Pennsylvania to Maine. Farms and mills in the region have been supplying restaurants and bakeries with local, fresh flour for several years. Retail sale of these products, to home cooks and bakers, has been increasing as well.

Multiple other markets exist for grain products, however, including craft beverages, animal feed, and biodiesel fuel. The craft beverage industry has been growing for several years across the Northeast. In 2012, New York State passed legislation to encourage brewery and distillery business development, creating farm brewery, distillery, and cider production licenses that require the use of New York agricultural products. Farm brewers and distillers must use 20 percent New York ingredients, to increase to 60 percent in 2019 and 90 percent in 2024 (New York State Governor's Office, 2013). Since 2005, there has been an increase of 278 breweries - 130 of which are farm breweriesand 124 distilleries in New York, with an estimated economic impact of US $\$ 27$ billion since 2012 (Empire State Development, 2017). The requirements for grain use paired with the growing demand for craft beer and spirits in New York markets signal a significant need to increase foodand beverage-grade grain production in New York State. Though these breweries and distilleries are reliant in large part on malting barley, there is growing interest in alternative grains such as wheat, rye, corn, and buckwheat as competition in the marketplace demands more interesting and unique flavor profiles.

Though New York State has passed the most aggressive legislation in support of these businesses, which has led to increased grain production in the state, other states are seeing growth in this sector as well. Vermont passed legislation in 1988 to allow for the operation of brewpubs, permitting the sale of beer in the same location it is brewed. Vermont is a leader in microbrewery and craft beer production; currently, the state has $51 \mathrm{craft}$ breweries in operation, the highest number of breweries per capita in the nation (Vermont Brewers Association, 2017; Vermont Pub \& Brewery, 2014). In 2014, craft breweries in Vermont had over US $\$ 199$ million in economic activity, supporting over 1,500 jobs (Kavet, Rockler \& Associates, LL, 2015). Maine currently has 82 breweries that employ over 1,600 people and that had an economic impact of over US $\$ 221$ million in 2016. Output has increased 25 percent since 2013 , and the state is expecting a 39 percent increase in 2018 and 41 percent by 2020 (Crawley \& Welsh, 2017).

The impact of the Northeast grains system reaches several layers of the regional economy. Malthouses returned to the Northeast with the 2009 launch of Valley Malt in Hadley, MA. Since then over a dozen malt businesses and hundreds of breweries and distilleries have sprung up. There are currently 14 malt houses in New York, while 10 
years ago there were none in the entire Northeast (Cazentre, 2017). In the last 10 years, at least four commercial flour mills started in the Northeast, and several more existing mills became reinvigorated with the availability of and demand for local flour. These businesses continue to create jobs, purchase crops from local and regional farms, support regional distributors, engage regional research institutions, and promote agricultural and food and beverage tourism.

Dairy and livestock farmers, recognizing consumer demand for organic and local products, are increasingly seeking certified organic grain for feed. Perhaps because they have access to land and equipment, some have begun turning part of their own fields over to grain production to produce their own feed (Lazor, 2013). This is a market opportunity for growers whose grain falls below beverage- and food-grade quality standards; beginning growers who are concerned with missing quality targets for beverage and food markets may find interested livestock farmers. This is especially attractive to transitional or organic growers who may experience quality disruptions. Additionally, by-product from food, beverage, and fuel grains, such as hulls, straw, bran, spent grain, and pellets from crushed oilseed are viable products for livestock feed. Animal feed is a market opportunity for forage crops that can be grown in rotation with food and beverage grains.

\section{Rotation Crops for Northeast Grain Farms}

Systems that incorporate crop rotation, when compared to monocropping systems, support soil health and farm level agro-ecology (Gliessman, 2016). The primary barriers to instituting these practices now are production capability and underdeveloped market demand. Existing farms may be more willing to incorporate increased crop diversity if there are demonstrated markets for the harvested product. The increased number of grain farms in the Northeast offers an opportunity for diverse products from field crop systems. Rotation offers various benefits for farmers, including multiple revenue streams in the event of crop loss, pest habitat disruption, and increased soil health. Rotation is an especially important practice for organic growers, who are prohibited from using synthetic fertilizers and pesticides. Having a range of crops offers consumers multiple products and product varieties for their specific needs.

Table 1 provides examples of rotation crops that perform well on Northeast farms. These crops include a variety of plant families that interact with soil, pests, and diseases in different ways. The crops have different root structures, nutrient needs

Table 1. Rotation Crops Suitable to the Northeast

\begin{tabular}{llll}
\hline Crop & End Use & Plant family & Benefits \\
\hline Dry Beans & Food, feed & Fabaceae & Fixes atmospheric nitrogen \\
\hline Buckwheat & Food & Polygonaceae & $\begin{array}{l}\text { Fine root structure, soil granulation, phosphorous extraction, } \\
\text { rapid growth }\end{array}$ \\
\hline Sunflower & Food, oil & Asteraceae & Deep taproot \\
\hline Canola & Food, oil & Brassicaceae & Cold tolerant \\
\hline Corn & Food, feed & Poaceae & \\
\hline Wheat & Food, feed & Poaceae & High value \\
\hline Oats & Food, feed & Poaceae & \\
\hline Emmer & Food & Poaceae & Drought and pest tolerant, high value \\
\hline Rye & Food, feed & Poaceae & Grows on poor soil, cold tolerant, winter cover \\
\hline Mustard Seed & Food, oil & Brassicaceae & \\
\hline Flax & Food, oil, fiber & Linaceae & High value \\
\hline
\end{tabular}

Sources: Kroeck, 2011; Lazor, 2013; Rogosa, 2016. 
and recycling ability, and marketability. These provide multiple benefits to farmers by increasing soil organic matter- thereby increasing waterholding capacity and decreasing fertilizer requirements - protecting against total crop loss, generating multiple revenue streams, and increasing the potential for long-term farm resiliency (Kroeck, 2011).

Legumes are grown in rotation with grains to replenish nutrients back into the soil by transferring atmospheric nitrogen into the soil. This process makes nitrogen, essential for plant growth, available for the following year's crop, thus reducing the need for synthetic fertilizers. In addition, legumes interfere with many pest and disease cycles that become common when a field is left in a single crop year after year. By alternating between leguminous crops and grasses (grain crops), pest and disease loss is often lessened. Expanding rotation to include a greater variety of crops increases resiliency even further (Kroeck, 2011; Lazor, 2013; Lengnick, 2015).

Common legume crops in the region are black beans, kidney beans, clover, and alfalfa. Combineready peas and beans in the Northeast offer largescale farms the capacity to grow legumes in rotation with grains and offer institutional buyers the option for more standardized ingredients in larger volumes. Higher-value legumes offer increased revenue for farmers and access to more interesting and better-tasting products for consumers. Heirloom beans command higher prices in specialty markets across the region. Challenges for specialty beans, however, include a clean seed supply and delicate post-harvest handling procedure (Gifford, 2015; Lazor, 2013).

Recognizing the need for rotation, some businesses, such as Vermont Bean Crafters, have begun to focus on rotation crops to increase environmental and food system sustainability. The company began in 2010 with the goal of increasing production of staple crops in Vermont and enhancing farm diversity. It coordinates with over a dozen growers in Vermont and New York to produce and process up to a thousand pounds (454 $\mathrm{kg}$ ) of dry beans per week (Gifford, 2015). Vermont Bean Crafters also produces several value-added products, such as bean burgers, that are sold to institutions such as hospitals and care facilities, the University of Vermont food services, and Vermont school food programs. These products replace commodity products with items produced from crops that economically and ecologically benefit regional farms (Carter, 2013; Gifford, 2015).

Oilseeds, such as sunflower, canola, and flax, may be better suited to larger-scale production than the region currently provides. Nevertheless, these crops, as they belong to different families with different growth stages and root structures than grasses and legumes, are beneficial additions to crop rotations. The harvested crops may be used in the form of whole seed for human or livestock consumption, pressed for culinary oil, and pressed and refined for biodiesel. Waste product produced by pressing for oil can also be sold as livestock feed. These processes may be done by outside enterprises or, depending on the scale involved, performed on the farm itself, providing lucrative value-added products for farmers. More research is needed to evaluate and identify varieties of other oilseed crops such as flax and pumpkin suitable for field crop systems.

\section{Discussion and Conclusions}

There is an important distinction between understanding the importance of crop rotation and having the resources and market opportunity to increase farm diversity through crop rotation. Structural and social support are essential elements for more widespread adoption of diversitypromoting farm management practices (Kirschenmann, 2010). Farmers are generally aware of the benefits of crop rotation for soil health and pest resistance, as researchers have been investigating and promoting crop rotation for many years and numerous programs and organizations are gaining a better understanding of these processes and interactions. However, market development for a wide range of crops is critical for making a substantive transition to diverse systems. Local and sustainable food systems professionals are needed to engage and develop markets for rotation crops as a means of encouraging the adoption of diverse cropping systems

The markets for high-quality bread wheat and 
malting barley have been demonstrated, following years of research and commitment by various organizations and businesses. Attention must remain fixed on the overall goals of agro-ecological stewardship and farm resilience, in order to establish financial independence for farmers in the face of increased food system consolidation and the effects of climate change. Policy and economic incentives, such as the New York Craft Act, Vermont microbrewery laws, farm-to-institution programs, Greenmarket's 15 percent flour rule and the Greenmarket Regional Grains Project, and research and grant work provided and supported by NGGA, OGRIN, NOFA/Mass, Cornell University, UVM, Penn State, MGA, Sustainable Agriculture Research and Education (SARE), and others have significantly affected development of the re-established Northeast grains industry. With collaboration from diverse stakeholders, more work can be accomplished to engage markets, increase demand for diverse crops, and increase farm revenue and overall resiliency. Ideally, stakeholders and advocates for sustainable regional food systems would work with bakers, chefs, brewers, distillers, livestock producers, millers, and grain farmers to further develop demand for legumes, oilseeds, ancient grains, forages, and other rotation crops.

There are several areas for further study and engagement. Technical assistance is needed for developing diverse crop systems on regional farms. The availability of equipment to handle various grains and field crops on the farm and throughout the supply chain is deficient in the Northeast and is a limiting factor for system expansion. Institutional support-from local and state departments of agriculture, food policy, and economic development-is needed to promote and encourage multiple-crops and farm conservation practices for resilient farming to become more widespread in the region. Education and outreach programs focusing on intermediary buyers and end-point consumers are needed to grow the marketplace for a greater diversity of field crops. Feedback mechanisms between farmers, processors, handlers, and consumers can be studied, strengthened, and formalized to increase efficiencies in sharing best practices, specifications, and needs throughout the supply chain.

\section{References}

Bland, A. (2013, June 25). Going against the grain: Small-scale grain farms are the next wave of the locavore movement. But can they actually make a profit? Slate. Retrieved from http://www.slate.com/articles/life/food/2013/06/ small_scale_grain_farmers_can_local_grains_be_profitable.html

Carter, R. (2013, July 1). Locally grown beans in the college cafeteria: Vermont's Farm to Plate Network offers farmer and producer examples of navigating the regional supply food chain to serve 'local' at institutions. Comell Small Farms Program Quarterly. Ithaca, NY: Cornell Cooperative Extension, Cornell Small Farms Program. Retrieved from http://smallfarms.cornell.edu/2013/07/01/locally-grown-beans-in-the-college-cafeteria/

Cazentre, D. (2017, September 21). 1886 Malt: Upstate NY's big new brewery supplier could be game-changer [Online newsgroup]. Syracuse, NY: Advance Media New York. Retrieved from http://www.newyorkupstate.com/breweries/2017/09/1886 malt upstate nys big new brewery supplier could be a game-changer.html

O'Dea, J.. (2013). Some resources on growing small grains in the Northeast. Kingston, NY: Cornell University Cooperative Extension-Ulster County. Retrieved from http://www.hort.cornell.edu/expo/proceedings/2016/Hops $\% 20$ and $\% 20$ Grains. $\% 20$ The $\% 20$ Cornell $\% 20$ malt $\% 20$ barley $\% 20$ update.pdf

Cornell University. (2017, July 20). Heritage and ancient grain project feeds a growing demand. ScienceDaily. Retrieved from www.sciencedaily.com/releases/2017/07/170720103129.htm

Crawley, A., \& Welsh, S. (2017). The economic impact of the craft brewing industry in Maine (Staff Paper SOE-630). Orono: University of Maine, School of Economics.

Cronon, W. (1991). Nature's metropolis: Chicago and the Great West. New York: W. W. Norton.

Empire State Development [ESD]. (2017). The case for building your craft beverage business in New York State—distilled. Albany: NYS Government, ESD. Retrieved from https://esd.ny.gov/industries/craft-beverage 
Gifford, A. (2015, Summer). Putting beans in the center of the plate. Quarterly Nensletter of the Northeast Organic Farming Association of Vermont. Richmond: NOFA-VT. Retrieved from https://nofavt.org/sites/default/files/files/resources/nofanotes summer2015.pdf

Gliessman, S. (2016). Transforming food systems with agroecology. Agroecology and Sustainable Food Systems, 40(3), 187-189. https://doi.org/10.1080/21683565.2015.1130765

GrowNYC. (2016). About Greenmarket's Regional Grains Project. New York: GrowNYC. Retrieved from https://www.grownyc.org/grains/about

Halloran, A. (2015). The new bread basket: How the new crop of grain growers, plant breeders, millers, maltsters, bakers, brewers, and local food activists are redefining our daily loaf. White River Junction, VT: Chelsea Green.

Heady, E. O. (1976). The agriculture of the U. S. Scientific American, 235(3), 106-127. https://doi.org/10.1038/scientificamerican0976-106

Heritage Grain Conservancy [HGC]. (n.d.). Heritage Grain Conservancy: Restoring the cuisine of forgotten grains. Colrain, MA: Author. Retrieved from http://growseed.org/About\%20HGC.pdf

Jacob, H. E. (2007). Six thousand years of bread: Its holy and unboly history. New York: Skyhorse.

Kavet, Rockler \& Associates, LLC. (2015). The economic impact of craft brewing on the Vermont economy in 2014. Belmont, MA: Kavet, Rockler \& Associates, LLC. Retrieved from http://legislature.vermont.gov/assets/Documents/2018/WorkGroups/Senate Economic Development/Vermont Brewers Association/W Sean Lawson Economic Study - VT Brewers Assoc. 11-11-2017.pdf

Kirschenmann, F. L. (2010). Cultivating an ecological conscience: Essays from a farmer philosopher. Berkeley, California: Counterpoint Press.

Koenig, L. (2010, March 22). The breadbasket of America: New England? The Atlantic. Retrieved from https://www.theatlantic.com/health/archive/2010/03/the-breadbasket-of-america-new-england/37830/

Kroeck, S. (2011). Crop rotation and cover cropping: Soil resiliency and bealth on the organic farm. White River Junction, Vermont: Chelsea Green.

Kucek, L. K., Dyck, E., Russell, J., Clark, L., Hamelman, J., Burns-Leader, S., ... Dawson, J. C. (2017). Evaluation of wheat and emmer varieties for artisanal baking, pasta making, and sensory quality. Journal of Cereal Science, 74, 19-27. https://doi.org/10.1016/j.jcs.2016.12.010

Lazor, J. (2013). The organic grain grower: Small-scale, holistic grain production for the home and market producer. White River Junction, Vermont: Chelsea Green.

Lengnick, L. (2015). Resilient agriculture: Cultivating food systems for a changing climate. Gabriola Island, British Columbia, Canada: New Society.

Low, S., Adalja, A., Beaulieu, E., Key, N., Martinez, S., Melton, A., ... Jablonski, B. (2015). Trends in U.S. local and regional food systems: Report to Congress (Administrative Publication No. 068). Washington, D.C.: USDA, Economic Research Service. Retrieved from https://www.ers.usda.gov/webdocs/publications/42805/51173_ap068.pdf?v=42083

Maine Grains Alliance [MGA]. (n.d.). History. Skowhegan, Maine: Maine Grains Alliance. Retrieved September 17, 2017, from http://kneadingconference.com/history/

Mars, M. M. (2015). The framing and celebration of the American local grain movement [Review of the book The New Bread Basket: How the New Crop of Grain Growers, Plant Breeders, Millers, Maltsters, Bakers, Brewers, and Local Food Activists Are Redefining our Daily Loaf, by A. Halloran]. Journal of Agriculture, Food Systems, and Community Development, 6(1), 209-211. https://doi.org/10.5304/jafscd.2015.061.002

New York State Governor's Office. (2013, October 9). Governor Cuomo welcomes 14 licensed farm breweries in New York State [Press Release]. Albany: NYS State Capitol Building. Retrieved from https://www.governor.ny.gov/news/governor-cuomo-welcomes-14-licensed-farm-breweries-new-york-state

Northeast Organic Farming Association-Massachusetts Chapter [NOFA/Mass]. (2014). Growing grain in Massachusetts. Barre, Massachusetts: NOFA/Mass. Retrieved from https://www.nofamass.org/events/growing-grainsmassachusets

Northern Grain Growers Association [NGGA]. (n.d.). Our association. St. Albans, Vermont: NGGA. Retrieved from http://northerngraingrowers.org/our-association 
Organic Growers' Research and Information Sharing Network [OGRIN]. (2017). About. Bainbridge, New York: OGRIN. Retrieved from http://www.ogrin.org/about

Pennsylvania State University [PSU]. (2013, February 14). Management for high-quality organic wheat and ancient grain production in the Northeast [Webinar]. eXtension.org. Retrieved from http://articles.extension.org/pages/66869/management-for-high-quality-organic-wheat-and-ancient-grainproduction-in-the-northeast

Platel, R., \& Russell, J. (2015). Meeting the demand for small grains in New York State [White paper]. Rensselaerville, New York: Carey Institute for Global Good and New York Empire State Development.

Razon, K. (2017). A guide to Northeast grains (Master's thesis, Green Mountain College, Poultney, Vermont). Retrieved from https://www.amazon.com/Guide-Northeast-Grains-Kristina-Razon-ebook/dp/B06W5DLKTV

Rogosa, E. (2012). Northeast organic wheat; an extension program for on-farm crop improvement in organic systems and local market partnerships (Final Report No. LNE08-270). College Park, Maryland: Sustainable Agriculture Research \& Education. Retrieved from https://projects.sare.org/project-reports/lne08-270/

Rogosa, E. (2016). Restoring heritage grains: The culture, biodiversity, resilience, and cuisine of ancient wheats. White River Junction, Vermont: Chelsea Green.

Sen, I. (2015, September 15). Against the grain: With local farms growing wheat, will New York revive its appetite for local grain? Edible Hudson Valley, Fall 2015. Retrieved from http://ediblehudsonvalley.ediblecommunities.com/food-thought/against-grain

University of Vermont [UVM] Extension. (2017). Northwest crops and soils program. Burlington, Vermont: University of Vermont Extension. Retrieved September 17, 2017, from http://www.uvm.edu/extension/cropsoil/

U.S. Department of Agriculture [USDA]. (2015). Dietary guidelines 2015-2020, Appendix 3: Healthy U. S.-style eating pattern. Washington, D.C.: USDA, Center for Nutrition Policy and Promotion. Retrieved from https://health.gov/dietaryguidelines/2015/guidelines/appendix-3/

USDA, National Agriculture Statistics Service [USDA NASS]. (2016). Total direct marketed sales of food and number of farms selling directly. Washington, D.C.: USDA NASS. Retrieved from https://www.agcensus.usda.gov/Publications/2012/Online Resources/Local Food/

Vermont Brewers Association. (2017). Economic impact. Burlington, Vermont: Author. Retrieved September 17, 2017, from https://www.vermontbrewers.com/about/economic-impact/

Vermont Pub \& Brewery. (2014). History. Burlington, Vermont: Vermont Pub \& Brewery. Retrieved October 16, 2017, from http://www.vermontbrewery.com/history 